\title{
Novel-Writing Competition for African Authors in East Africa
}

The Rockefeller Foundation has recently made a grant to be used by the East African Literature Bureau for the development of creative writing by Africans in East Africa. A Committee has been formed to assist and advise the Bureau in the use of this grant.

The Committee now announces that its first Competition, for the writing of novels in English, Luganda, and Swahili, is being held in $196 \mathrm{r}$. Further information may be obtained from: Novel Competition, East African Creative Writing Committee, c/o East African Literature Bureau, P.O. Box 30022 , Nairobi, Kenya.

\section{The Impact of the West and Social Change: International Seminar at Leyden}

AN international seminar for students and post-graduates was held in May at the University of Leyden, under the auspices of the Leyden branch of the National Federation of Students of Social Anthropology. One hundred and fifty students from Scandinavia, Germany, Portugal, Italy, and Switzerland met together with representatives from seven Dutch universities for the seminar, which included a session on African conditions. This was introduced in a lecture by Dr. John Middleton of University College, London, who discussed some trends resulting from the changes in East African communities as illustrated among four East African peoples-the Baganda and Lugbara of Uganda, and the Masai and Kikuyu of Kenya-and showed the considerable extent to which the aims of peoples under modern influences remain basically tribalistic. In a final survey Professor Dr. S. Hofstra, of the University of Leyden, stressed the importance of keeping in mind that the West itself is changing rapidly, and that every society has to allow itself a certain degree of irrationality and sentimental clinging to tradition in order to keep its values intact.

The success of this seminar has encouraged the Federation to plan another to be held in about two years' time at the University of Utrecht.

\section{(Communicated by Maarten G. Timmer)}

\section{Award for M. de Garine}

M. IGOR DE GARINe has recently been awarded the Prix Liotard for his work in North Cameroun. M. de Garine, who was awarded a field research fellowship by the Institute in I957, has just completed a study of the Massa of the Moyen-Logone which is to be published shortly.

\section{'Ethnology': a New Quarterly Journal}

THE Department of Anthropology at the University of Pittsburgh announces that a new quarterly journal, Ethnology, an international journal of cultural and social anthropology, will begin publication in January 1962. Subscriptions and applications for exchange should be addressed to the Editor, George P. Murdock, Department of Anthropology, University of Pittsburgh, Pittsburgh I3, Pennsylvania. Contributions are solicited from scientists in any country on any phase of cultural or social anthropology. 